\title{
Penerapan Model Blended POE2WE Untuk Meningkatkan Kreativitas Pada Pendidikan Anak Usia Dini Dalam Pembelajaran Sains
}

\author{
Sovi Ayudia Syahfi ${ }^{1}$ Nana $^{2}$ \\ ${ }^{1}$ Mahasiswa Program Studi Pendidikan Fisika,Universitas Siliwangi \\ ${ }^{2}$ Dosen Program Studi Pendidikan Fisika, Universitas Siliwangi \\ Program Pendidikan Fisika,Fakultas Keguruan dan Ilmu Pendidikan Universitas Siliwangi \\ Tasikmalaya, Indonesia \\ Email : Soviayudia17@gmail.com
}

\begin{abstract}
Abstrak
Penelitian ini bertujuan untuk : (1) mendeskripsikan langkah-langkah bagaimana caranya untuk meningkatkan kreativitas pada anak usia dini dengan menggunakan model POE2WE (2) menjelaskan bagaimana penerapan keterampilan untuk membangun suatu kreativitas pada anak usia dini (3) mengetahui pembelajaran sains pada anak usia dini. Dalam hal ini untuk bisa membangun kreativitas pada anak usia dini diperlukan suatu keterampilan dan ide yang sederhana agar mereka dapat memahami konsep dengan baik. Dengan bantuan menggunakan model POE2WE anak usia dini dapat melakukan suatu prediksi. Dengan prediksi inilah anak usia dini akan mengetahui bahwa pembelajaran sains juga dapat digambarkan terlebih dahulu.
\end{abstract}

Kata kunci: Model POE2WE, Kreativitas, Keterampilan

\section{Pendahuluan}

Model $\mathrm{POE}_{2} \mathrm{WE}$ merupakan model pembelajaran yang dikembangkan untuk mengetahui pemahaman peserta didik mengenai suatu konsep dengan pendekatan kontruktivistik. Model ini membangun pengetahuan dengan urutan proses yaitu meramalkan atau memprediksi solusi dari permasalahan, melakukan eksperimen untuk membuktikan prediksi, kemudian menjelaskan hasil eksperimen yang diperoleh secara lisan maupun tertulis, membuat contoh penerapan dalam kehidupan sehari-hari, menuliskan hasil diskusi dan memuat evaluasi tentang pemahaman peseta didik baik secara lisan maupun tertulis ( Nana et al.,2014).Perkembangan ilmu pengetahuan dan teknologi mengalami kemajuan yang sangat pesat seiring dengan perubahan zaman. Begitu pula perkembangan ilmu pengetahuan pada dunia pendidikan menuntut perubahan sistem pendidikan nasional,supaya masyarakat khususnya anak mampu bersaing dan menyesuaikan diri dengan perubahan dan perkembangan zaman saat ini dan yang akan datang. Peningkatan kualitas pada berbagai jenis dan jenjang pendidikan termasuk PAUD,TK dan SD merupakan titik berat pembangunan pendidikan pada saat ini dan pada waktu yang akan datang. Pendidikan anak usia dini adalah upaya pembinaan yang ditujukan kepada anak sejak lahir sampai usia enam tahun yang dilakukan melalui pemberian rangsangan pendidikan untuk membantu pertumbuhan dan perkembangan jasmani. Selain itu pula Pendidikan anak usia dini adalah pendidikan untuk memfasilitasi pertumbuhan dan perkembangan anak secara menyeluruh dalam pengembangan suatu aspek.Bidang pengembangan kemampuan dasar merupakan kegiatan yang dipersiapkan oleh guru untuk meningkatkan kemampuan dan kreativitas sesuai dengan tahap perkembangan anak, meliputi : berbahasa, kognitif, fisik atau motorik dan seni. Kognitif sendiri adalah mengembangkan kemampuan berpikir anak untuk dapat 
mengolahperolehan belajarnya, sehingga dapat menemukan bermacam-macam alternatif pemecahan masalah,membantu anak untuk mengembangkan kemampuan logika matematika dan kemampuan sains. Anak pada usia dini mengalami fase fundamental bagi perkembangannya yang disebut the golden age atau usia emas. Salah satu aspek penting yang perlu dikembangkan dalam pembelajaran pendidikan anak usia dini (PAUD) dan TK yaitu salah satunya pembelajaran sains. Menurut Ali Nugraha ( 2005: 1) mengemukakan bahwa pengembangan pembelajaran sains pada anak, termasuk bidang pengembangan lainnya yang memiliki peranan sangat penting dalammembantu meletakkan dasar kemampuan dan pembentukan sumber daya manusia yang diharapkan. Tujuan pengembangan pembelajaran sains untuk anak adalah agar anak memiliki kemampuan memecahkan masalah yang dihadapinya melalui metode sains,meningkatkan kemampuan sains pada anak, diharapkan anak memiliki sikap ilmiah dan diharapkan anak lebih berminat untuk menghayati sains.

Menurut (John W. Haefele dalam Munfarijah ; 2018),Kreativitas merupakan kemampuan untuk membuat sesuatu yang baru dan bernilai sosial. Menurut ( Suroso dalam Husna Handayani ; 2018), kreativitas merupakan kebutuhan pada masa kini dan masa yang akan datang. Kreativitas diperlukan agar dapat menjemput abad persaingan pengembangan kreativitas seseorang yang menghasilkan karya inovatif atau sesuatu yang baru dan dibutuhkan pada zaman sekarang. Menurut (Santrock dalam Yosep ; 2014),kreativitas ialah suatu kemampuan dalam berfikir mengenai sesuatu dengan menggunakan cara yang tidak biasa dalam menyelesaikannya masalah. Menurut ( Sujiono dalam Ardiyanto ; 2017), kreativitas ialah kemampuan saat memikirkan,menciptakan, mengadakan dan menemukan suatu bentuk ataupun gagasan baru yang origilan yang bisa berguna bagi orang itu sendiri dan orang lain. Menurut ( Setyabudi dalam Istiqomah ; 2017 ), kreativitas merupakan proses penyatuan pengetahuan dari berbagai macam bidang pengalaman yang berlainan dalam menghasilkan ide-ide yang bermanfaat dengan menggunakan cara baru dengan lebih baik serta mampu merealisasikannya. Menurut ( Suluso dalam Djuniartiningsih ; 2012), kreativitas ialah aspek kognitif yang mendatangkan hasil dengan cara pandangan baru terhadap suatu masalah atau situasi. Menurut ( Fauziddin ; 2016) , kreativits merupakan kemampuan menciptakan produk baru baik yang benar-benar baru maupun memodifikasi apa yang sudah ada menjadi baru. Menurut ( NACCE ( National Advisory Committee on Creative and Cultural Education) dalam Nirwana, Widyaningsih, dan Sapaile ; 2019), kreativitas ialah suatu aktivitas yang dilakukan dengan imajinasi dan menghasilkan hal baru dan bernilai.

Bahwa untuk meningkatkan suatu kreativitas pada anak usia dini dibutuhkan strategi dan tahap. Diantaranya menurut (Wallas dalam Priyanto ; 2014), ada tempat tahap dalam proses kreatif yaitu : (1) Persiapan, (2) Inkubasi, (3) Iluminasi dan (4) Verifikasi. Selain strategi adapula yang dapat meningkatkan kreativitas yaitu strategi. Menurut Rachmawati mengatakan bahwa ada beberapa strategi yang dapat mengembangkan kreativitas anak yaitu : (1) pengembangan kreativitas dengan menciptakan produk ( hasrat karya), bertjuan mengembangkan kreativitas pada anak dan kognitif anak dalam menciptakan produk dengan mengajak anak membentuk sesautu secara bebas, (2) mengajak anak untuk bereksplorasi agar dapat mengembangkan kreativitasnya, karena anak bisa belajar secara langsung dari pengalamannya, (3) mengajak anak melakukan kegiatan eksperimen untuk belajar memecahkan suatu masalah, (4) pengembangan kreativitas melalui kegiatan proyek dilakukan secara berkelompok untuk membuat sebuah hasil karya, (5) melibatkan indra pendengar dan alat-alat musik, anak diajak untuk berkreasi dengan musik, (6) pengembangan melalui bahasa adalah kegiatan yang bisa dilakukan dengan cara mendongeng, menceritakan pengalaman yang didengarkan, (7) pengembangan kreativitas melalui imajinasi, karena strategi ini sudah melekat dilakukan dalam diri anak, sehingga kegiatan yang melibatkan 
imajinasi anak akan membantu anak dalam mengembangkan kreativitas ( Sari, Antara, \& Ujianti ; 2017 ).

Menurut ( Paul Torrance dari Universitas Georgia dalam Miranda ; 2018 ), menyebutkan ada beberapa ciri-ciri tindakan kreatif anak yaitu: (1) anak yang kreatif belajar menggunakan dengan cara-cara kreatif, (2) anak yang kreatif mempunyai perhatian yang panjang terhadap sesuatu hal yang dibutuhkan usaha menjadi kreatif, (3) anak kreatif dapat mengorganisasikan terhadap hal yang tidak biasa, (4) anak kreatif banyak belajar melalui imanjinasi untuk memecahkan suatu permasalahn dari pengalaman yang pernah di alami, (5) anak kreatif dapat bercerita dengan menggunakan kata-kata dan tempat sebagai objeknya. Menurut (Susanto dalam Fauziah, 2018), ada empat dimensi (4P) kreativitas yang saling berkesinambungan yaitu: (1) Pribadi ( person), (2) kreatif dengan dengan melibatkan diri pada proses ( process), (3) kreatif dengan memberikan dukungan dan (4) dorongan ( pess) dari lingkungan.

Menurut(Fakhriyani ; 2018) kreativitas anak usia dini dapat ditingkatkan dengan menggunakan berbagai cara seperti mendongeng, menggambar dan bermain dengan menggunakan alat, selain itu suasana yang harus diciptakan juga menyenangkan bagi anak. Menurut ( Kartini \& Sujarwo ; 2017 )meningkatkan kreativitas anak usia dini dapat menggunakan permainan, karena permainan merupakan salah satu media yang dapat memotivasi anak untuk mengurangi rasa bosan dan jenuh pada saat kegiatan belajar mengajar. Pada model $\mathrm{POE}_{2} \mathrm{WE}$ adanya penerapan PPK ( Penguatan Pendekatan karakter) dan Abad 21, terdapat nilai-nilai religius, gotong royong, kerja keras dan nasionalisme (Nana ; 2014).

\section{Metode Penelitian}

Penelitian ini menggunakan metode literasi (studi pustaka) dengan cara mengkaji berbagai literatur yang berkaitan dengan penerapan model $\mathrm{POE}_{2} \mathrm{WE}$ (Kearney, 2004; Kearney \& Young, 2007; Nana, 2014, 2016; Nana, Saji dan, Akhyar, \& Rochsatiningsih, 2014; Permatasari, 2011; Rahayu, Widodo, \& Sudirman, 2013; Samosir, 2010; Supriyati, 2012) dan pembelajaran Blended Learning (Bersin, 2004; Purwaningsih \& Pujianto, 2009; Thorne, 2003). Dan cara untuk meningkatkan kreativitas pada anak usia dini.

\section{Hasil dan Pembahasan}

\section{Model POE2WE}

Model pembelajaran Prediction, Observation, Explanation, Elaboration,Write dan Evaluation $\left(\mathrm{POE}_{2} \mathrm{WE}\right)$ dikembangkan POEW dan model pembelajaran Fisika dengan pendekatan Kontruktivistik ( Nana et al ; 2014). Dalam model ini anak usia dini dapat menjadi lebih aktif karena mereka bisa mengembangkan ide kreativitas mereka dengan cara berimajinasi dan memprediksi konsep apa yang sedang di jelaskan oleh guru mengenai pembelajaran sains, misalnya dengan permainan menggunakan dua buah magnet, mengenal sistem tata surya, dan mengenali warna primer dan sekunder. Maka anak usia dini bisa untuk berimajinasi terlebih dahulu.

Penggabungan tahapan- tahapan pembelajaran model POEW dan model pembelajaran Fisika dengan pendekatan Konstruktivistik maka dapat disusun langkah-langkah pembelajaran model $\mathrm{POE}_{2} \mathrm{WE}$ secara terinci sebagai berikut:

a) Prediction

Tahap prediction yaitu peserta didik membuat prediksi atau dugaan awal terhadap suatu permasalahan. Permasalahan yang ditemukan berasal dari pertanyaan dan 
gambar tentang materi yang disampaikan oleh guru yang ada di Lembar Kerja peserta didik ( LKS) atau buku peserta didik sebelum peserta didik membuat prediksi.

\section{b)Observation}

Tahap Observation yaitu untuk membuktikan prediksi yang telah dibuat oleh peserta didik. Peserta didik diajak melakukan eksperimen berkaitan dengan masalah atau persoalan yang di temukan. Selanjutnya peserta didik mengamati apa yang terjadi, kemudian peserta didik menguji kebenaran dari dugaan sementara yang telah dibuat.

b) Explanation

Tahap Explanation atau menjelaskan yaitu peserta didik memberikan penjelasan terhadap hasil eksperimen yang telah dilakukan. Penjelasan dari peserta didik dilakukan melalui diskusi dengan anggota kelompok kemudian tiap kelompok mempresentasikan hasil diskusinya di depan kelas.

c) Elaboration

Tahap elaboration yaitu peserta didik membuat contoh atau menerapkan dalam kehidupan sehari-hari.

d) Write

Tahap write atau menulis yaitu melakukan komunikasi secara tertulis, mereflesikan pengetahuan dan gagasan yang dimiliki peserta didik. Menurut (Wisniowska ; 1996 dalam Yamin \& Ansari ; 2012)Masingilia dan menulis dapat membantu peserta didik untuk mengekspresikan pengetahuan dan gagasan mereka. Peserta didik menuliskan hasil diskusi dan menjawab pertanyaan yang ada pada LKS. Selain itu, pada tahap write ini peserta didik membuat kesimpulan dan laporan dari hasil eksperimen.

e) Evaluation

Tahap Evaluation yaitu evaluasi terhadap pengetahuan, keterampilan dan perubahan proses berfikir peserta didik.

Dengan menggunakan model $\mathrm{POE}_{2} \mathrm{WE}$ pada anak usia dini dalam pembelajaran sains, misalnya guru menggunakan magnet. Guru akan mengambil dua buah magnet, guru memberi tahu kepada anak bahwa jika magnet ini dilepas maka anak-anak harus berkata " hi " dan ketika guru menempelkan magnetnya maka anak-anak harus berkata" hello". Dengan begitu sang anak mampu berimajinasi dan memprediksi apakah magnet itu akan dilepas atau ditempel. Karena menyampaikannya dalam bentuk permainan maka anak-anak tidak akan mudah cepat merasa bosan. Sesudah itu ternyata guru melepas dan menempel magnet itu maka anak-anak akan tahu yang terjadi pada magnet itu. Lalu anak-anak dapat menyebutkan apabila magnet dilepas maka anak-anak harus berkata"hi" dan ketika magnet ditempel maka anak-anak harus berkata " hello". Dan guru juga menjelaskan keterkaitan magnet dengan kehidupan sehari-hari bahwa pertemanan harus selalu bersama dan tetap menjaga pertemanan. Lalu permainan magnet itu bisa dilakukan oleh anak-anak usia dini. Dan masih banyak pembelajaran sains yang dapat digunakan dalam suatu permainan. Ini sesuai dengan Menurut ( Kartini \& Sujarwo ; 2017 )meningkatkan kreativitas anak usia dini dapat menggunakan permainan, karena permainan merupakan salah satu media yang dapat memotivasi anak untuk mengurangi rasa bosan dan jenuh pada saat kegiatan belajar mengajar.Karena pada dasarnya mengajarkan pembelajaran sains kepada anak usia dini itu 
tidak mudah, maka dari itu diperlukan suasana belajar yang menyenangkan agar tidak cepat merasa bosan.

Maka ketika anak melakukan suatu prediksi,anak akan mulai berfikir kreatif dan akan berkolaborasi dengan temannya. Misalnya ketika magnet dilepas maka mereka bukan lagi menyebutkan" hi" melainkan nama buah "apel" dan ketika magnet di tempelkan mereka bukan lagi menyebutkan " hello" melainkan " anggur", dan ketika ide itu muncul,maka guru

dapat membentuk suatu kelompok untuk mereka bermain bersama teman-temanya dan masih berkaitan dengan pembelajaran sains. Keterampilan Proses Sains

Selain tahap dan strategi yang dapat meningkatkan kreativitas, adapula yang dapat meningkatkan kreativitas pada anak usia dini yaitu suatu keterampilan proses sains. Menurut ( Ali Nugraha 2005 ; 128),keterampilan proses sains yang dapat dilatihkan pada anak meliputi kemampuan: (1) Mengamati yaitu anak melibatkan kombinasi dari beberapa atau seluruh alat indera, didalamnya terdapat kegiatan melihat, mendengaar,meraba, mencicipi,mencium. (2) mengklasifikasikan yaitu suatu sistematika yang digunakan untuk mengatur obyek-obyek ke dalam sederetan kelompok tertentu, kegiatannya antara lain: mencari persamaan, membandingkan, mencari dasar pengklasifikasiannya obyek-obyek dengan menggolongkan berdasarkan pada satu atau lebih ciri/sifat atau fungsinya. (3) mengkomunikasikan yaitu kegiatan ini melibatkan kemampuan mengutarakan dalam bentuk lisan, tulisan, gambar dan grafik.

Pada keterampilan ini anak usia dini dapat menggambar. Misalnya menggambar suatu planet dan bisa menyebutkan planet-planet tersebut bahkan mengklasifikannya. Maksudnya setelah guru menyebutkan nama- nama planet, anak -anak itu tahu bahwa yang sedang disebutkan oleh gurunya adalah nama-nama planet. Guru terlebih dahulu akan memberi tahu dan menjelaskan planet-planet yang ada pada tata surya dan memperlihatkan gambar dari planet-planet tersebut.

\section{Blended POE $2 \mathrm{WE}$}

Kerangka teori $\mathrm{POE}_{2} \mathrm{WE}$ ini dibangun berdasarkan pandangan dari beberapa teori yang mengkerangkai model pembelajaran $\mathrm{POE}_{2} \mathrm{WE}$. Dalam $\mathrm{POE}_{2} \mathrm{WE}$ dipadukan tiga jenis interaksi yang meliputi interaksi sosial, interaksi muatan, dan interaksi dosen. Penjelasan adalah sebagai berikut:

a. Tipe interaksi pertama adalah dengan dosen yang menjadi fasilitator active learning dan interaksi tatap muka yang terjadi pada suatu setting sosial. Akan tetapi dosenlah yang merancang dan mengelola urut-urutan pembelajaran dan menyeleksi media yang tepat sebelum berinteraksi dengan mahasiswa. Tips pertama ini bisa digunakan pada pembelajaran sains pada anak usia dini. Karena pada anak usia dini diperlukan interaksi yang sering dengan gurunya. Karena rasa ingin tahu yang tinggi maka anak-anak akan bertanya kepada gurunya. Misalnya bertanya tentang nama-nama planet.

b. Interaksi kedua adalah dengan muatan interaksi ini menjembatani interaksi kognitif dengan konsep- konsep dan keterampilan yang termuat dalam modul pembelajaran. Modul tersebut disertai dengan petunjuk penggunaan dan mind mapping setiap topik sehingga tujuan pembelajaran tergambar dengan jelas. Untuk anak usia dini maka guru akan memberikan suatu buku yang berisi gambargambar yang sesuai dengan pembelajaran sains. 
Terakhir, interaksi sosial dimaksudkan sebagai kemampuan pembelajar ( siswa) untuk mempersepsikan diri mereka sebagai sebuah komunitas yang saling bergantung secara positif ( positive interdependent,cooperation). Interaksi yang demikian itu dapat terjadi dikeseluruhan proses pembelajaran karean mereka mengerjakan tugas-tugas yang menuntut kerja sama. Sebagaimana diketahui dimensi interaksi ( diskursus social). Makna ini kemudian dibagi antara anggotaanggota kelompok yang ikut membangun pengetahuan bersama melalui tanggapan antar mereka sendiri. Ini sudah merupakan pencapaian level kognitif yang tinggi(Aviv;2005) Pembelajaran pada anak usia dini, guru dapat membagikan kelompok untuk mereka menganal nama-nama tata surya misalnya. Dan nama anak-anak tersebut diganti menjadi nama tata surya. Misalnya anak ke 1 diberi nama mars,lalu anak ke 2 bumi, anak ke tiga saturnus dan begitu seterusnya. Kelompok yang kalah nyanyi lagu anak-anak. Ini bisa melatih komunuikasi anakanak dan juga daya ingat pada anak-anak.

\section{Kesimpulan}

Berdasarkan hasil penelitian dengan menggunakan metode studi pustaka, bahwa dengan menggunakan model $\mathrm{POE}_{2} \mathrm{WE}$ dapat meningkatkan kreativitas pada anak usia dini dengan menggunakan langkah-langkahnya. Dan keterampilan juga sangat diperlukan untuk membangun suatu kreativitas pada anak usia dini. Dalam pembelajaran sains pada anak usia dini dapat memperkenalkannya dengan cara permainan.

\section{Ucapan Terima Kasih}

Peneliti mengucapkan terima kasih kepada Dr.Nana,M.Pd. Selaku dosen pengampu dan semuanya yang telah membantu demi kesempurnaan artikel ini menjadi lebih baik.

\section{Daftar Pustaka}

Ali Nugraha. ( 2005). Pengembangan Pembelajaran Sains pada Anak Usia Dini.Jakarta : Departemen Pendidikan Nasional

Ardiyanto, A. (2017). Bermain Sebagai Sarana Pengembangan Kreativitas Anak Usia Dini. Jendela Olahraga. https://doi.org/10.26877/jo.v2i2.1700

Djuniartiningsih. (2012). Meningkatkan Kreativitas Anak K Lompok B Di Tk " Merpati Pos" Surabaya Universitas Negeri Surabaya. Jurnal UNESA.

Fakhriyani, D. V. (2018). Pengembangan Kreativitas Anak Usia Dini. Wacana Didaktika, 4(2), 193-200. https://doi.org/10.31102/wacanadidaktika.4.2.193-200

Fauziah, N. (2018). Penggunaan Media Bahan Alam Untuk Meningkatkan Kreativitas Anak. JIV, 8(1), 23-30. https://doi.org/10.21009/jiv.0801.4

Fauziddin, M. (2016). Penerapan Belajar Melalui Bermain Balok Unit untuk Meningkatkan Kreativitas Anak usia Dini. Meningkatkan Kreativitas Anak Usia Dini. Jurnal Curricula, 1(3), 1-11, https://doi.org/http://dx.doi.org/10.22216/JCC. 2016.v2i3.1277. 
Miranda, D. B. C. B. P. K. (2018). Akter Untuk Meningkatkan Kreativitas Aud. Jurnal Visi Ilmu Pendidikan, 10(1), 18. https://doi.org/10.26418/jvip.v10i1.25975

Munfarijah,S. (2018). Upaya Meningkatkan Motivasi Kerja dan KreativitasDalam.Kepemimpinan PAUD.Jurnalkependidikan ， 3(2), 162182.https://doi.org/10.24090/jk.v3i2.905.

Husna Handayani, P. (2018). Pengembangan Kreativitas Anak Usia Dini DalamKeluarga. JurnalKeluargaSehat Sejahtera.https://doi.org/10.24114/jkss.v15i2.8774.

Istiqomah, D. (2017). Kreativitas dan Pengembangannya dalam Perspektif Teori Ernst Kris. Golden Age: Jurnal Ilmiah Tumbuh Kembang Anak Usia Dini.

Kartini, K., \& Sujarwo, S. (2017). Penggunaan Media Pembelajaran Plastisin Untuk Meningkatkan Kreativitas Anak Usia. Jurnal Pendidikan Dan PemberdayaanMasyarakat, 1(2), 199. https://doi.org/10.21831/jppm.v1i2.2689

Nana. (2014). Pengembangan model POE2WE dalam pembelajaran Fisika.Universitas Sebelas Maret.

Nana. (2016). Pengembangan model Pembelajaran Prediction, Observation, Explanation, Elaboration, Write, and Evaluating ( POE2WE) dalam Pembelajaran Fisika SMA. Universitas Sebelas Maret.

Nana, Sajidan, Akhyar,M,. \& Rochsatiningsih, D. ( 2014). The development of predict, Observe, Explain, Elaborate, Write, and Evaluate ( POE2WE) Learning Model in physics Learning at Senior Secondary School. Journal Of Education and Pratice.

Nirwana, N., Widyaningsih, O., \& Sapaile, N. (2019). Pelatihan Kreativitas Clay Bagi Guru Paud Kecamatan Tambora, Jakarta Pusat. Sarwahita, 15(01), 13-21. https://doi.org/10.21009/sarwahita.151.02

Sari, L. P. P., Antara, P. A., \& Ujianti, P. R. (2017). Pengaruh Strategi Permainan Imajinatif terhadap Kreativitas Anak Kelompok B Gugus III Kecamatan Buleleng. Journal Pendidikan Anak Usia Dini.

Priyanto, A. (2014). Pengembangan Kreativitas Pada Anak Usia Dini Melalui Aktivitas Bermain. Pengembangan Kreativitas Pada Anak Usia Dini Melalui Aktivitas Bermain.

Yosep, W.(2014). Pembelajaran music kreatif pada anak usiadini (the learning of creative music and early childhood children. Harmonia Jurnal of Art Reseaerch and education. 5(1), 190-200. 